\title{
Sistem Pendukung Keputusan Pemilihan Tempat Usaha Potensial dengan Metode SAW (Studi Kasus : SahabatLink Tasikmalaya)
}

\author{
Hendri Mahmud Nawawi ${ }^{\star 1}$, Yudhistira Yudhistira², Ali Mustopa ${ }^{3}$, Siti Khotimatul Wildah ${ }^{4}$, Sarifah \\ Agustiani $^{5}$, Muhammad Iqbal ${ }^{6}$ \\ ${ }^{1}$ Teknik Informatika, Universitas Nusa Mandiri \\ 2,4,5,6Teknologi Komputer, Universitas Bina Sarana Informatika \\ ${ }^{3}$ Teknologi Informasi, Universitas Bina Sarana Informatika \\ Email: 1hendri.hiw@nusamandiri.ac.id, 2yudhistira.yht@bsi.ac.id, 3alimustopa.aop@bsi.ac.id, \\ ${ }^{4}$ siti.ska@bsi.ac.id, ${ }^{5}$ sarifah.sgu@bsi.ac.id, ${ }^{6 m u h a m m a d . m d q @ b s i . a c . i d ~}$
}

\begin{abstract}
Abstrak
Memutuskan tempat untuk membuka usaha adalah hal yang sangat penting dan wajib diperhatikan saat akan memulai bisnis baru atau membuka cabang, sejumlah faktor penting diperhitungkan supaya dapat meminimalisir resiko kerugian di masa yang akan datang sehingga tujuan dari bisnis yaitu meningkatkan keuntungan bisa dicapai secara maksimal, pada penelitian ini sejumlah faktor dicatat dan dijadikan sebagai kriteria untuk menilai tempat usaha yang layak dan potensial berdasarkan hasil observasi dan pengamatan di lapangan pada tempat usaha dengan merk dagang SahabatLink dengan menggunakan metode Simple Additive Weight. Konsep metode SAW adalah mencari penjumlahan terbobot berdasarkan rating kinerja dari setiap alternatif yang ditambahkan dengan banyak kriteria. Hal ini yang menjadikan metode ini tepat digunakan untuk menentukan keputusan memilih tempat usaha potensial dengan banyak kriteria diantaranya akses, visibilitas, lalu lintas, persaingan, jarak ke tempat keramaian, tempat parkir, biaya sewa, ekspansi dan konduktivitas. Hasil akhir dari penjumlahan kriteria inputan dengan metode SAW dapat menjadi rekomendasi bagi pihak manajemen untuk membuka tempat usaha berdasarkan nilai alternatif yang paling tinggi.
\end{abstract}

Kata kunci: Sistem Pendukung Keputusan, Simple Additive Weight, Tempat Usaha, SahabatLink

\begin{abstract}
Deciding where to open a business is very important and must be considered when starting a new business or opening a branch, a number of important factors are taken into account in order to minimize the risk of loss in the future so that the purpose of the business, namely increasing profits can be achieved maximally, in research. This number of factors is recorded and used as criteria for assessing a feasible and potential business place based on the results of observations and observations in the field at the place of business with the SahabatLink trademark using the Simple Additive Weight method. The concept of the SAW method is to find a weighted addition based on the performance rating of each alternative that is added with many criteria. This is what makes this method appropriate to use to determine the decision to choose a potential business place with many criteria including access, visibility, traffic, competition, distance to crowded places, parking space, rental costs, expansion and conductivity. The final result of the sum of the input criteria using the SAW method can be a recommendation for management to open a business place based on the highest alternative value.
\end{abstract}

Keywords: Decision Support System, Simple Additive Weight, Place of Business, SahabatLink

\section{PENDAHULUAN}

Layanan keuangan tanpa Bank atau dikenal dengan nama LAKU PANDAI sebagaimana diatur oleh Otoritas Jasa Keuangan (OJK) Nomor 19/POJK.03/2014 Layanan Keuangan Tanpa Kantor Dalam Rangka Keuangan Inklusif yang selanjutnya disebut Laku Pandai adalah kegiatan menyediakan layanan 
Indonesian Journal on Software Engineering (IJSE)

Vol. 7, No. 1, Juni 2021, hlm. 26-34

p-ISSN: 2461-0690

Akreditasi KEMENRISTEKDIKTI, No. 85/M/KPT/2020

e-ISSN: 2714-9935

perbankan dan/atau layanan keuangan lainnya yang dilakukan tidak melalui jaringan kantor, namun melalui kerjasama dengan pihak lain dan perlu didukung dengan penggunaan sarana teknologi informasi.

Dengan memanfaatkan teknologi informasi yang saat ini mudah diakses lahan bisnis ini menjadi primadona dikalangan masyarakat yang mempunyai modal untuk digulirkan pada bisnis layanan konsumen ini, keuntungan yang didapatkan biasanya bagi hasil dari biaya administrasi dan reward dari nominal transaksi (Otoritas Jasa Keuangan, 2014). SahabatLink adalah salah satu merk dagang yang memanfaatkan layanan ini dengan prinsip melayani konsumen dengan dekat dan cepat. Sebelum membuka gerai untuk memulai bisnis beberapa faktor dipertimbangkan sehingga income yang diperoleh diharapkan sesuai dengan ekpetasi. Memilih lokasi bisnis secara efektif berarti meminimalkan risiko negatif, atau dengan kata lain, mendapatkan lokasi dengan risiko positif terbesar (Nur Fu'ad, 2015).

Dari hasil penelitian beberapa faktor penting yang perlu diperhatikan saat akan membuka usaha diantaranya akses, visibilitas, lalu lintas, persaingan, jarak ke tempat keramaian, tempat parkir, biaya sewa, ekspansi dan konduktivitas adalah hal yang mempengaruhi keputusan memilih tempat usaha potensial. Pada penelitian ini metode Simple Additive Weighting (SAW) digunakan untuk mempertimbangkan alternatif terbaik dari beberapa faktor sebagaimana disebutkan yang dijadikan inputan sebagai kriteria dalam menentukan keputusan memilih tempat potensial untuk membuka usaha dengan banyak faktor atau Multiple Criteria Decision Making (MCDM) (Ramadhan, Mazia, \& Pujiastuti, 2019).

Pada dasaranya konsep metode SAW adalah mencari penjumlahan terbobot berdasarkan rating kinerja dari setiap alternatif yang dimasukan atau pada semua atribut (Nurlela, Akmaludin, Hadianti, \& Yusuf, 2019). Kinerjanya metode ini membutuhkan proses normalisasi matriks keputusan (x) ke suatu skala yang dapat dibandingkan dengan semua rating alternatif yang ada (Ismanto \& Effendi, 2017). Metode SAW membutuhkan proses standarisasi matriks keputusan (X) untuk mencapai skala yang dapat dibandingkan dengan semua level alternatif yang tersedia. Metode ini merupakan metode yang terkenal dan paling banyak digunakan untuk menangani situasi pengambilan keputusan multi atribut (MADM), metode ini digunakan untuk mencari alternatif terbaik dari beberapa alternatif dengan kriteria tertentu (Angrawati, Yamin, \& Ransi, 2016).

Penelitian sebelumnya (Mulyadin \& Winarso, 2019) metode SAW digunakan untuk alternatif pemilihan smartphone yang memudahkan pelanggan untuk memilih smartphone yang sesuai keinginan konsumen. Penelitian selanjutnya penentuan pemberian pinjaman kepada anggota Bumdes memberikan rekomendasi kepada pihak pengurus untuk menilai kriteria peminjam yang layak untuk diberi pinjaman dengan metode SAW (Nurul Putri Utami, Hasanul Fahmi, \& Anita Sindar, 2019). Metode SAW digunakan untuk menentukan keputusan penerimaan karyawan di Universitas Muhammadiyah Riau, karena proses penerimaan sumber daya manusia memerlukan metode yang profesional dan akurat untuk menghasilkan sumber daya manusia yang dapat menunjang mutu dan keberhasilan perguruan tinggi (Ismanto \& Effendi, 2017).

Berdasarkan cara kerja dan hasil penelitian sebelumnya metode SAW ini cocok dijadikan sebagai pengambilan keputusan memilih tempat usaha potensial pada SahabatLink karena mempertimbangkan banyak faktor sebagai nilai inputan.

\section{METODE PENELITIAN}

Pada penelitian ini penulis menggunakan metode penelitian kualitatif dan kuantitatif dimana data yang dihasilkan adalah data yang diambil dari hasil riset dilapangan kemudian diberikan point untuk masing-masing kriteria berdasarkan pengalaman dan observasi, metode observasi ini dimaksudkan sebagai tahapan penelitian dengan mengamati objek yang akan dipelajari (Mustopa, Agustiani, Wildah, \& Maysaroh, 2020). Pengumpulan data dilakukan dengan mengumpulkan dokumen, jurnal, makalah dan bahan bacaan yang ditetapkan sebagai referensi (Fridayanthie, Azis, \& Kusumaningrum, 2018), tujuan dengan penelitian ini dirancang untuk mengetahui dan menetapkan pola perubahan dimasa lampau yang digunakan untuk meramalkan keadaan dan pola masa datang (Yusuf, 2016). Tahapan penelitian pada makalah ini dijelaskan pada gambar 1 


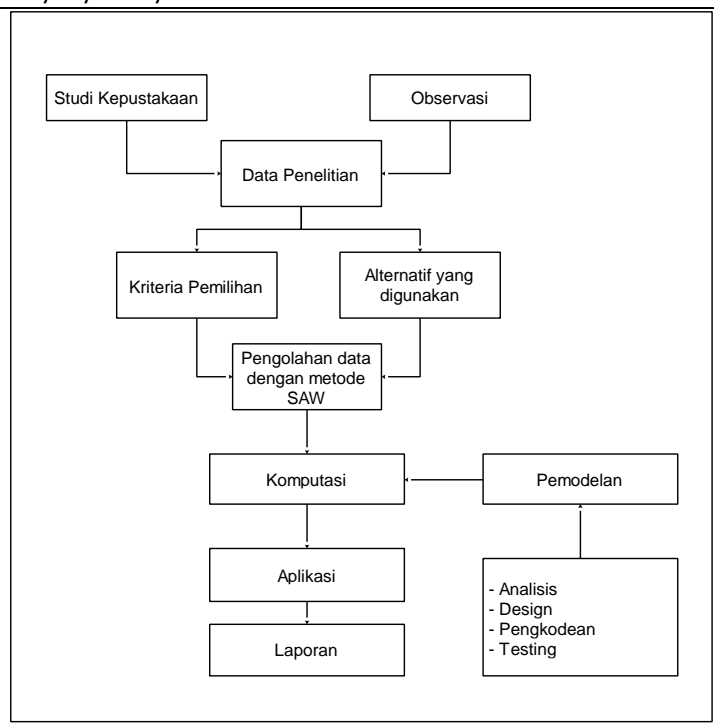

Gambar 1. Tahapan Penelitian

Pengolahan data pada penelitian ini secara lengkap dengan menggunakan metode Simple Additive Weight adalah sebagai berikut tahapannya:

a. Menentukan alternatif, yaitu Ai.

b. Menentukan kriteria yang akan dijadikan acuan dalam pengambilan keputusan, yaitu Cj.

c. Memberikan nilai rating kecocokan setiap alternatif pada setiap kriteria yang telah dimasukan kedalam tabel.

d. Menentukan bobot preferensi atau tingkat kepentingan (W) setiap kriteria. Dimana rumus untuk menentukan prefensinya adalah :

$\mathrm{W}=[\mathrm{W} 1, \mathrm{~W} 2, \mathrm{~W} 3, \ldots, \mathrm{WJ}]$

e. Membuat tabel rating kecocokan dari setiap alternatif pada setiap kriteria

f. Membuat matrik keputusan $(X)$ yang dibentuk dari tabel rating kecocokan dari setiap alternatif pada masing-masing kriteria. Nilai $X$ setiap alternatif $(\mathrm{Ai})$ pada setiap kriteria $(\mathrm{Cj})$ yang sudah ditentukan, dimana, $\mathrm{i}=1,2, \ldots \mathrm{m}$ dan $\mathrm{j}=1,2, \ldots \mathrm{n}$.

$$
x=\left[\begin{array}{cc}
x 11, x 12, \ldots & x 1 j \\
\ldots & \ldots \\
x i 1, x i 2, \ldots & x i j
\end{array}\right]
$$

g. Melakukan normalisasi matrik keputusan dengan cara menghitung nilai rating kinerja ternomalisasi (rij) dari alternatif Ai pada kriteria $\mathrm{Cj}$.

$$
r i j= \begin{cases}\frac{x i j}{M a x X i j} & \rightarrow J i k a j \text { adalah attribut keuntungan (benefit) } \\ \frac{M i n X i j}{X i j} & \rightarrow J i k a j \text { adalah attribut biaya (cost) }\end{cases}
$$

\section{Dimana :}

$\mathrm{Ri} \mathrm{j}=$ nilai rating kinerja ternormalisasi

$\mathrm{Xi}=$ nilai atribut yang dimiliki dari setiap kriteria

Max $\mathrm{xij}=$ nilai terbesar dari setiap kriteria $\mathrm{i}$

Min $\mathrm{xij}=$ nilai terkecil dari setiap kriteria $\mathrm{i}$

Benefit $=$ jika nilai terbesar adalah terbaik

Cost $=$ jika nilai terkecil adalah terbaik

Dimana rij adalah rating kinerja ternormalisasi dari alternatif $A i$ pada atribut $\mathrm{Cj} ; \mathrm{i}=1,2, \ldots, \mathrm{m}$ dan $j=1,2, \ldots, n$. 
Indonesian Journal on Software Engineering (IJSE)

Vol. 7, No. 1, Juni 2021, hlm. 26-34

h. Hasil dari nilai rating kinerja ternomalisasi (rij) membentuk matrik ternormalisasi (R)

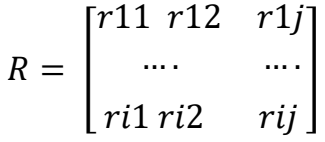

i. Hasil akhir nilai preferensi (Vi) diperoleh dari penjumlahan dari perkalian elemen baris matrik ternormalisasi $(\mathrm{R})$ dengan bobot preferensi $(\mathrm{W})$ yang bersesuaian eleman kolom matrik $(\mathrm{W})$

$$
V i=\sum_{j=1}^{n} W j r i j
$$

Di mana :

$\mathrm{Vi}=$ rangking untuk setiap alternatif

wj = nilai bobot dari setiap kriteria

rij = nilai rating kinerja ternormalisasi

Nilai Vi yang lebih besar mengindikasikan bahwa alternatif Ai lebih terpilih

\section{HASIL DAN PEMBAHASAN}

\subsection{Pemilihan Kriteria}

Sebelum membuat sebuah sistem pendukung keputusan dengan metode Simple Additive Weight maka langkah pertama yang harus diperhatikan adalah menentukan kriteria apa saja yang dipilih berdasarkan data hasil observasi dan kajian pustaka (Rahayu, Gumilang, Bharodin, \& Faturahman, 2020). Kriteria yang dipilih secara umum disajikan pada tabel 1.

\begin{tabular}{|c|c|c|}
\hline No & Kriteria yang dinilai & Keterangan \\
\hline 1 & Akses & $\begin{array}{l}\text { Lokasi yang mudah dijangkau atau dilalui sarana } \\
\text { transportasi umum }\end{array}$ \\
\hline 2 & Visibilitas & $\begin{array}{l}\text { Lokasi yang dapat dilihat dengan jelas dari tepi } \\
\text { jalan }\end{array}$ \\
\hline 3 & Lalu lintas (traffic) & $\begin{array}{l}\text { Banyaknya mobilitas penduduk atau kendaraan } \\
\text { yang lalu lalang }\end{array}$ \\
\hline 4 & Persaingan & Observasi terhadap usaha sejenis \\
\hline 5 & $\begin{array}{l}\text { Jarak ke tempat } \\
\text { keramaian }\end{array}$ & Misalnya pasar atau pusat kota (alun-alun) \\
\hline 6 & Tempat parkir & $\begin{array}{l}\text { Lahan untuk menyimpan kendaraan saat transaksi } \\
\text { dilakukan }\end{array}$ \\
\hline 7 & Biaya sewa & Biaya yang dibayarkan dalam hal ini sewa bulanan \\
\hline 8 & Ekspansi & $\begin{array}{l}\text { Tersedia tanah/ tempat yang cukup luas untuk } \\
\text { keperluan perluasan usaha dikemudian hari }\end{array}$ \\
\hline 9 & Konduktivitas & $\begin{array}{l}\text { Kebutuhan antara produk atau layanan yang } \\
\text { ditawarkan sesuai dengan lingkungan sekitar }\end{array}$ \\
\hline
\end{tabular}

Tabel 1. Kriteria Penilaian

Setelah mimilih kriteria apa saja yang ditentukan, langkah selanjutnya memberikan bobot penilaian. Dimana bobot penilaian di sajikan pada tabel 2 .

Tabel 2. Bobot Penilaian

\begin{tabular}{lc}
\hline \multicolumn{1}{c}{ Kriteria } & Bobot \\
\hline Sangat Layak & 5 \\
\hline Layak & 4 \\
\hline Cukup Layak & 3 \\
\hline Kurang Layak & 2 \\
\hline Sangat tidak layak & 1 \\
\hline
\end{tabular}




\subsection{Rancangan UML}

\section{a. Usecase Diagram}

Diagram use case digunakan untuk memahami proses yang direkomendasikan pada aplikasi berbasis web (Nawawi, Sutisna, \& Ichsan, 2019). Berikut adalah gambaran diagram use case yang diusulkan untuk Decision Support System (DSS) pemilihan tempat usaha potensial. Usecase diagram dijelaskan pada gambar 2 .

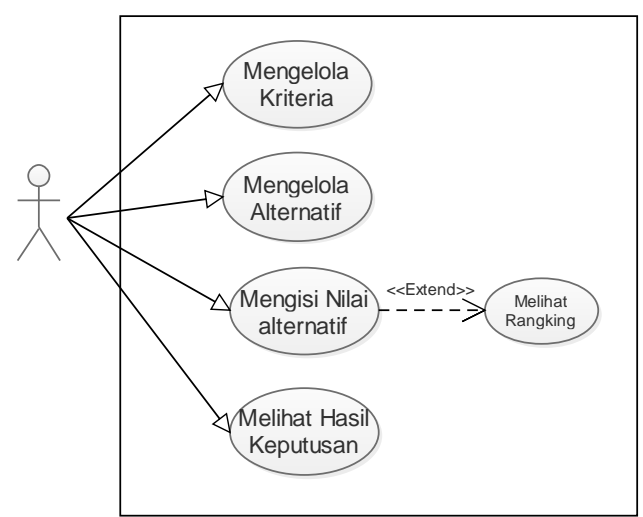

Gambar 2. Use Case Diagram

Skema Use Case adalah sekumpulan deskripsi tekstual dari skema interaktif. Setiap skenario menjelaskan serangkaian tindakan/langkah yang berhasil atau gagal saat aktor saat berinteraksi dengan sistem (Kurniawan, 2018). Penjelasan sekenario usecase diagram dijelaskan pada tabel 3

Tabel 3. Sekenario Use Case Diagram

\begin{tabular}{ll}
\hline Use Case diagram SPK pemilihan tempat usaha \\
\hline Tujuan & $\begin{array}{c}\text { Mengijnkan administrator untuk mengelola sistem } \\
\text { informasi }\end{array}$ \\
\hline Aktor & Administrator \\
\hline Kondisi Awal & Login tervalidasi dan Valid \\
\hline Skenario awal & 1. Admin memilih menu kriteria \\
2. Admin memilih menu alternatif
\end{tabular}

\section{b. Activity Diagram}

Diagram aktivitas menggambarkan alur kerja (work flow) atau aktivitas suatu sistem atau proses bisnis (Hendini, 2016). Diagram aktivitas adalah gambaran rinci dari aliran data dalam sistem desain. Diagram aktivitas menunjukkan bagaimana aliran dimulai, kemungkinan keputusan yang mungkin terjadi, dan bagaimana aliran berakhir (Kurniawan, 2018). Aktivitas diagram dijelaskan pada gambar 3. 


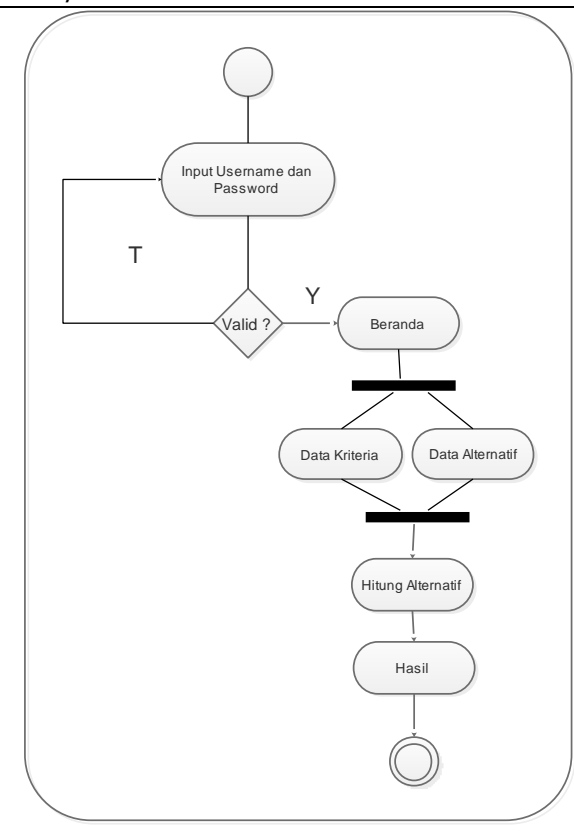

Gambar 3. Aktivity Diagram

\subsection{Implementasi Metode SAW dengan Studi Kasus}

a. Interface Halaman Login

Pada halaman ini administrator harus menginputkan username dan password yang valid agar masuk ke sistem

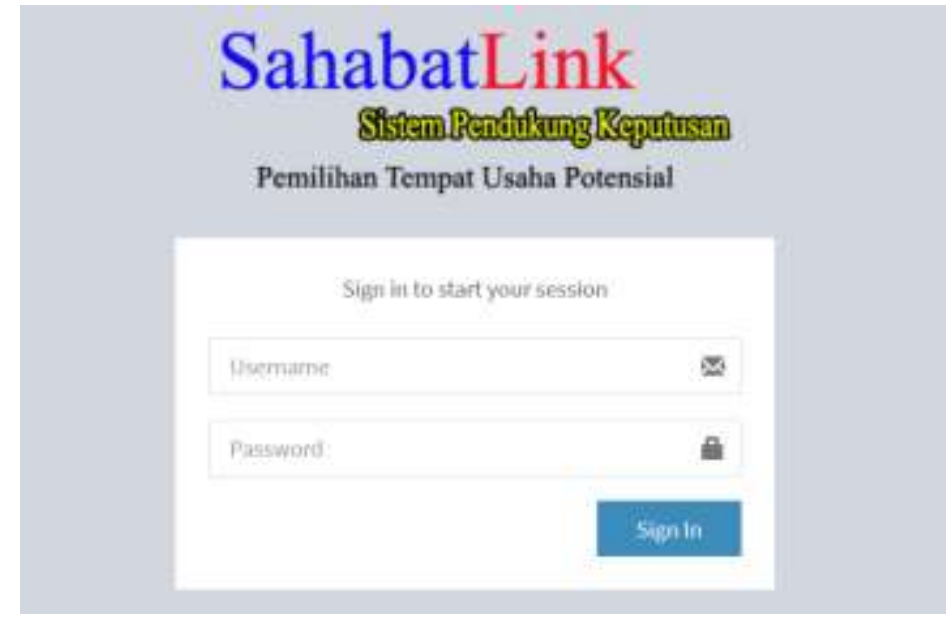

Gambar 4. Interface Halaman Login

b. Interface Halaman Kriteria

Pada halaman ini adalah gambaran dari interface penambahan data kriteria yang telah ditentukan berdasarkan studi kasus dan hasil observasi. Dimana bobot yang di masukan mewakili seberapa besar tingkat kelayakannya. 
c. Halaman Alternatif

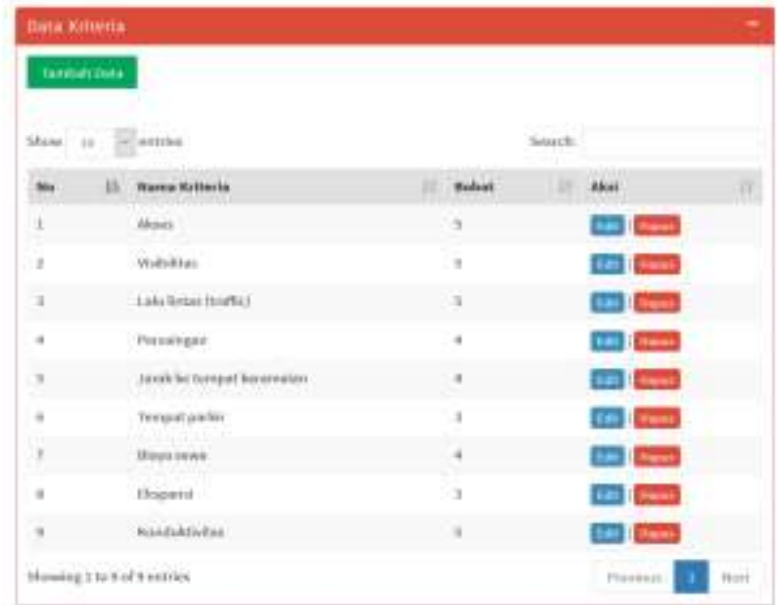

Gambar 5. Interface Data Kriteria

Pada halaman alternatif diisi data tempat usaha yang dijadikan pertimbangan untuk membuka cabang baru. Pada halaman ini data alternatif bisa di tambah, dihapus dan diubah serta button tambahan lain detail untuk melihat rincian data alternatif.

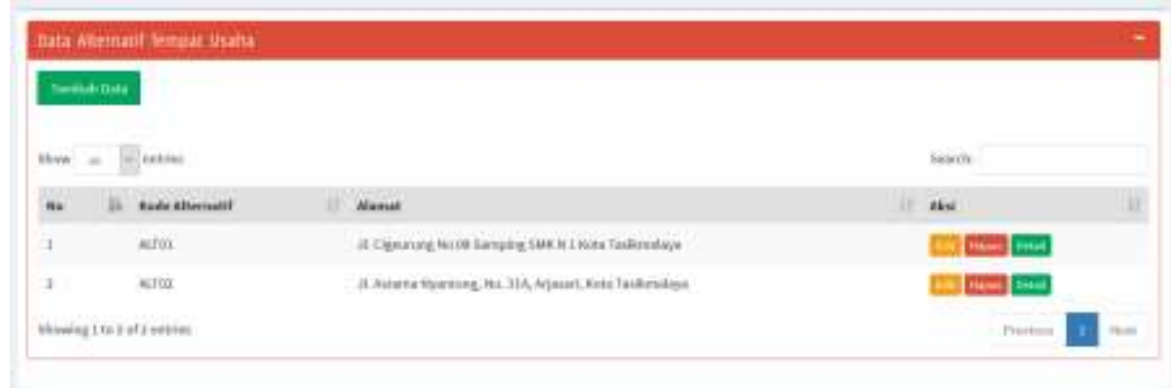

Gambar 6. Interface Halaman Alternatif

d. Penilaian Bobot Alternatif

Pada halaman ini user menginputkan data nilai dimana range penilaianya adalah 0 sampai 1 dengan kelipatan 0,25. Tujuannya untuk memberikan tingkat pengaruh dari masing-masing kriteria

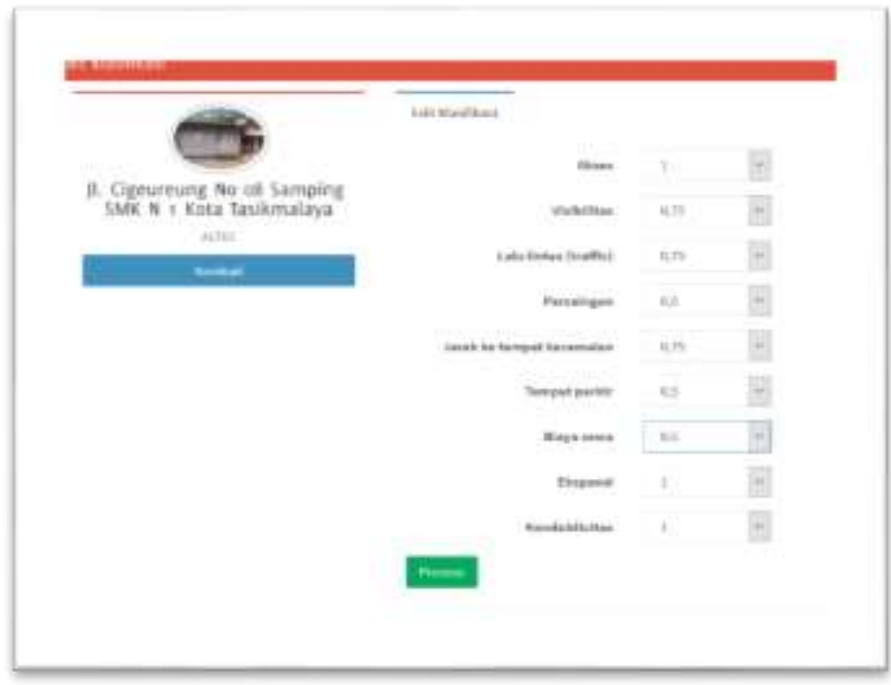

Gambar 7. Interface Halaman Penilaian Bobot Alternatif 
Indonesian Journal on Software Engineering (IJSE)

Vol. 7, No. 1, Juni 2021, hlm. 26-34

p-ISSN: 2461-0690

Akreditasi KEMENRISTEKDIKTI, No. 85/M/KPT/2020

e. Penilaian dengan metode SAW

1) Nilai Matrik Awal

Nilai matriks awal diinputkan sebagaimana nilai dari masing-masing kriteria, hasilnya bisa dilihat pada gambar 8

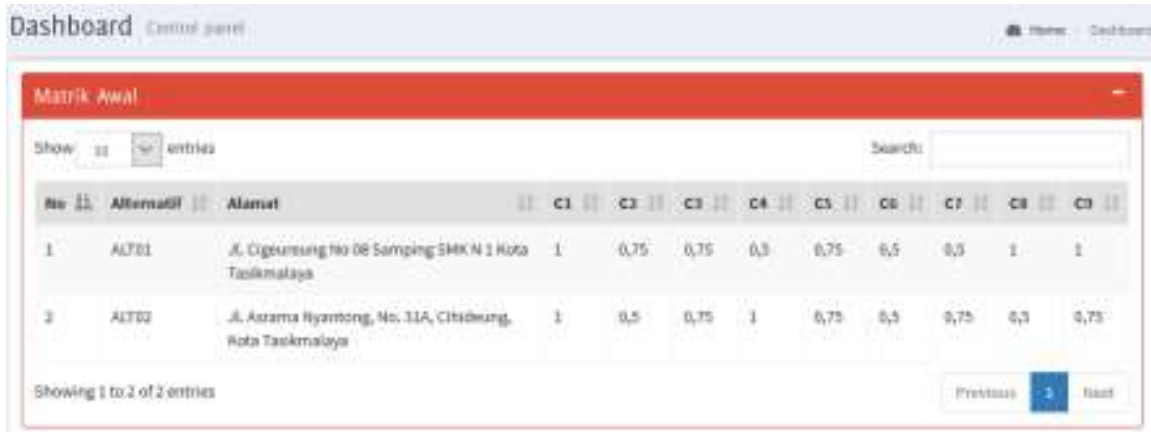

2) Konversi Nilai Matriks

Gambar 8. Interface Nilai Matriks Awal

Pada kolom ini nilai matriks awal dikonversi untuk dihitung dengan nilai bobotnya atau nilai kelayakannya.

3) Normalisasi data

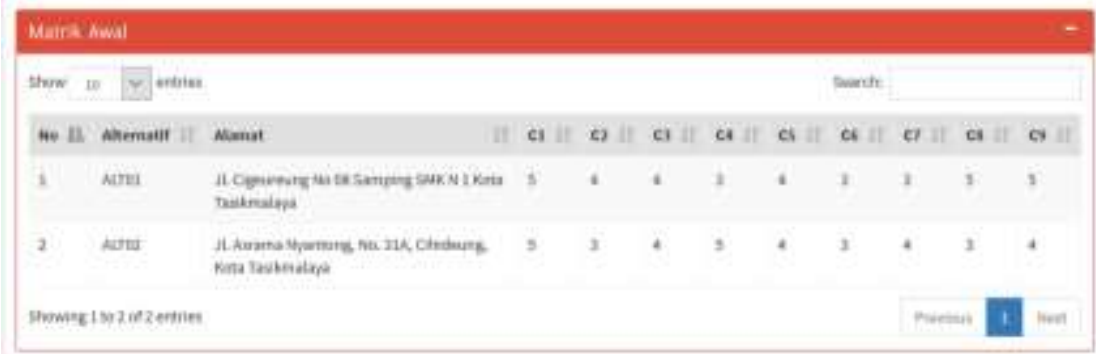

Gambar 9. Interface Konversi Nilai Matriks Awal

Melakukan normalisasi matrik keputusan dengan cara menghitung nilai rating kinerja ternomalisasi dari alternatif Ai pada masing-masing kriteria.

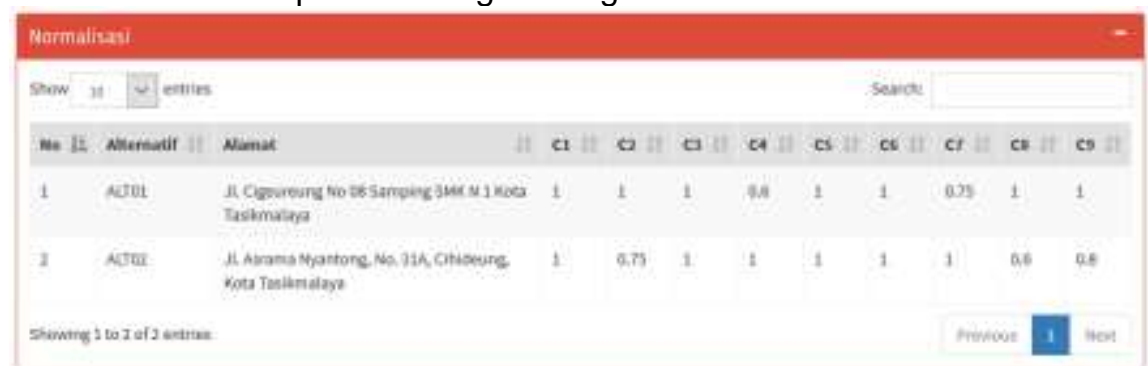

Gambar 10. Interface Halaman Normalisasi

4) Perangkingan

Langkah terakhir adalah dengan melihat rangking dari alternatif yang di inputkan dengan ini dapat diambil kesimpulan alternatif mana yang paling baik nilainya.

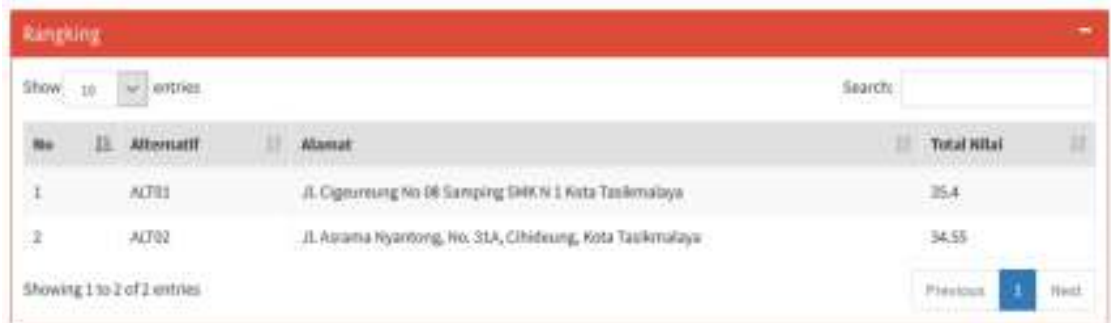

Gambar 11. Interface Halaman Perangkingan

Dari hasil perangkingan pada gambar 11 dihasilkan nilai untuk masing-masing alternatif dimana alternatif ke 1 dengan data ALT01 memiliki nilai 35,4 dan alternatif ke 2 ALT02 memiliki nilai 34,55. Hasil ini didapatkan dari hasil perhitungan dengan menggunakan metode SAW yang inputannya multi kriteria. 
Indonesian Journal on Software Engineering (IJSE)

Vol. 7, No. 1, Juni 2021, hlm. 26-34

p-ISSN: 2461-0690

Akreditasi KEMENRISTEKDIKTI, No. 85/M/KPT/2020

e-ISSN: 2714-9935

Dari hasil tersebut nilai alternatif paling tinggi adalah yang direkomendasikan oleh sistem untuk dijadikan keputusan apabila ingin membuka kios atau cabang baru alternatif paling minim resiko dan diprediksi bisa mengahasilkan income paling besar adalah alternatif ke satu atau ALT01 yaitu tempat usaha yang beralamat di Jl. Cigeureung No. 08 samping SMKN 1 Kota Tasikmalaya.

\section{5) KESIMPULAN}

Berdasarkan hasil penelitian dan observasi dilapangkan dengan sembilan kriteria yang telah diinputkan diantaranya akses, visibilitas, lalu lintas (traffic), persaingan, jarak ke tempat keramaian, tempat parkir, biaya sewa, ekspansi dan konduktivitas dari dua alternatif yang dijadikan pembanding alternatif pertama berdasarkan hasil perhitungan dan rekomendasi dengan metode Simple Additive Weighting (SAW) lokasi yang berada dialamat Jl. Cigeureung No 08 Samping SMK N 1 Kota Tasikmalaya adalah alternatif terbaik jika ingin membuka lahan usaha atau cabang baru karena memiliki nilai total alternatif sebesar 35,4 lebih besar daripada alternatif kedua yang menghasilkan nilai total 34,55.

\section{REFERENSI}

Angrawati, D., Yamin, M., \& Ransi, N. (2016). Sistem Pendukung Keputusan Menentukan Jumlah Beras Miskin Menggunakan Metode Simple Additive Weight (SAW). SemanTIK, 2(1), 39-45.

Fridayanthie, E. W., Azis, M. A., \& Kusumaningrum, A. (2018). Rancang Bangun (Sistem Informasi ELearning Berbasis Web Pada Smk Daarut Taufiq Tangerang. Swabumi, 6(2), 123-127. https://doi.org/10.31294/swabumi.v6i2.4560

Hendini, A. (2016). PEMODELAN UML SISTEM INFORMASI MONITORING PENJUALAN DAN STOK BARANG (STUDI KASUS: DISTRO ZHEZHA PONTIANAK). JURNAL KHATULISTIWA INFORMATIKA, IV(2), 107-116. https://doi.org/10.2135/cropsci1983.0011183x002300020002x

Ismanto, E., \& Effendi, N. (2017). Sistem Pendukung Keputusan Penerimaan Karyawan Dengan Metode Simple Additive Weighting (SAW). SATIN - Sains Dan Teknologi Informasi, 3(1), 1. https://doi.org/10.33372/stn.v3i1.208

Kurniawan, T. A. (2018). Pemodelan Use Case (UML): Evaluasi Terhadap beberapa Kesalahan dalam Praktik. Jurnal Teknologi Informasi Dan Ilmu Komputer, 5(1), 77. https://doi.org/10.25126/jtiik.201851610

Mulyadin, I., \& Winarso, D. S. (2019). Sistem Pendukung Keputusan Pemilihan Smartphone Menggunakan Metode Simple Additive Weighting. CAHAYAtech, 7(2), 88. https://doi.org/10.47047/ct.v7i2.13

Mustopa, A., Agustiani, S., Wildah, S. K., \& Maysaroh, M. (2020). Analisa Kepuasan Pengguna Website Layanan Akademik Kemahasiswaan (LYKAN) UBSI Menggunakan Metode Webqual 4.0. Jurnal Perspektif, 18(1), 75-81. https://doi.org/10.31294/jp.v18i1.7413

Nawawi, H. M., Sutisna, H., \& Ichsan, N. (2019). Sistem Pendukung Keputusan Pemberian Kredit Kendaraan Roda Dua Menggunakan Metode TOPSIS (Studi Kasus PT. Central Sentosa Finance Ciamis). Jurnal Infokar, 1(23), 301-316.

Nur Fu'ad, E. (2015). Pengaruh Pemilihan Lokasi Terhadap Kesuksesan Usaha Berskala Mikro/Kecil Di Komplek Shopping Centre Jepara. Media Ekonomi Dan Manajemen, 30(1), 56-67.

Nurlela, S., Akmaludin, A., Hadianti, S., \& Yusuf, L. (2019). Penyeleksian Jurusan Terfavorit Pada Smk Sirajul Falah Dengan Metode Saw. Jurnal Pilar Nusa Mandiri, 15(1), 1-6. https://doi.org/10.33480/pilar.v15i1.1

Nurul Putri Utami, Hasanul Fahmi, \& Anita Sindar. (2019). Spk Penentuan Pemberian Pinjaman Kepada Anggota Bumdes Dengan Metode Simple Additive Weighting. SINTECH (Science and Information Technology) Journal, 2(2), 124-130. https://doi.org/10.31598/sintechjournal.v2i2.317

Otoritas Jasa Keuangan. (2014). Salinan Peraturan Otoritas Jasa Keuangan Nomor 19/POJK.03/2014.

Rahayu, S., Gumilang, A. J. T., Bharodin, O. P., \& Faturahman, F. (2020). METODE ENTROPY-SAW DAN METODE ENTROPY-WASPAS DALAM MENENTUKAN PROMOSI JABATAN BAGI KARYAWAN TERBAIK DI CUDO COMMUNICATIONS. Jurnal Teknologi Informasi Dan IImu Komputer (JTIIK), 7(5), 1069-1078. https://doi.org/10.25126/jtiik.202072888

Ramadhan, S., Mazia, L., \& Pujiastuti, E. (2019). Sistem Pendukung Keputusan Pemilihan Sepeda Motor Bebek Dengan Metode Simple Additive Weighting. Indonesian Journal on Software Engineering (IJSE), 4(2), 74-81. https://doi.org/10.31294/ijse.v4i2.5986

Yusuf, A. M. (2016). Metode Penelitian Kuantitatif, Kualitatif \& Penelitian Gabungan. Jakarta: Prenada Media. 